\title{
The right to dismiss a worker in Italy, particularly the right to dismiss on the ground of objective reasons
}

\author{
Barbara Grand
}

\section{THE RIGHT TO DISMISS; STATUTORY LAW DEVELOPMENTS}

The Italian Constitution (signed in 1945, right after the Second World War) states that Italy is a democratic Republic grounded on labour (article 1), and affirms that the Republic recognises to all citizen the right to work, promoting the conditions that make such a right to be effective (article 4). There is no formal disposition in the Constitution allowing to any worker the assurance to be not dismissed, since labour can be provided by employers whose economic initiative is supposed to be free (art. 41); in a liberal economy, there is no forced business as there is not forced labour.

Nevertheless, enterprises/employers's right to do business must be granted in accordance with the principle that any economic initiative must pursue a social utility, and it cannot be performed by putting at risk social security, freedom and human dignity (art. 41 co. 2); therefor, according to Constitution, employees have the right, on their part, to claim that employers do pursue social utility, without putting at risk social security, freedom and human dignity.

The 1942 Civil Code general disposition (article 2119) states that interruption of the employment relation can be provoked - by both parties - on a reason that makes impossible for the relation to continue, insofar reconizing the two parties as acting on the same level, having the same contractual power to interrupt the contract: "both the parties of a work relation can resign from the contract before its termination, and in case employment is permanent, resignation is lawfull in case it happens something that does not even allow to temporarily continue it". Such a norm was, and still is, theoretically justified by a vision of permanent work contracts that "cannot stand on its own", rather needing a statutory determination for labour to be told stable, in other words, employment needs a statutory provision affirming its permanent nature ${ }^{1}$.

Today, according to 2015 novel by D.lgs n. 81 the dependent employment relationship, established on a permanent base, is to be considered the common form of employment in Italy - this is based on 2014 Jobs Act provision (2014 L. n. 183), expressingly committing "the Governament to promote, coherently with European provisions, permanent contracts by making them more convenient in respect with other other type of contracts as for direct and indirect deductions".

Since 1942, political fights and collective actions, with connected collective agreements, have led to a progressive limitation on the employers' power to dismiss in contrast with the Civil Code provision; newely considering the worker as the weaker party, rather than on the same

1 Statutory provisions are supposed to be coherent with the Consitutional Chart, and they can be judicially attacked once they contrast with it. 
level as the employer, such normative evolution has been possibile because of the support by judges of the new Constitutional regime.

The Italian Constitutional Court, with a decision dated 1965 (n. 45) regarding article 4 of the Charter, had the occasion to clarify that statutory laws can limit the employer's power (as granted by article 41) in such a fundamental aspect accordingly, insofar the Charter does cover the right to work only, not the right to keep one's job position as well. The Court added, nevertheless, that the legislator is called to assure the continuity of the employment relation whenever the employment is settled not temporarily but on a permanent base. Therefore, it can be argued that to be arbitrarily dismissed is against constitutional norms protecting the fundamental right to work, as a defensive argument, insofar criteria to ascertain arbitrairness can be found in statutes.

There after, conditions for arriving to the first statutory law ruling specifically the power to dismiss were settled and the 1966 Legge n. 604 was published on August the 6th; according to that it was, and still it is, possibile to dismiss on the ground of a subjective reason (like an employee's negligence in performing the contract can be) or on the ground of an objective reason (like an economic crises on the part of the employer can be).

The 1965 decision by the Constitutional Court has being criticized, although its ruling lasted for many decades after, for having not considered, together within the meaning of article 4 (and thereof article 1 too) the important perspective of self employment, which is nevertheless protected at a Constitutional level: article 35 of the Charter protects labour in all its forms and applications, and by denying such a protection, the constitutional judges led towards a substancial vision wherein continuity of employment should be granted (by law) in case of dependent work only, while continuity of self employment was not concerned. This finds an explanation on the fact that self employment was, and still is, much grounded on family connections and familiar structures, more than on the typically bilateral, an purely economic, employment relation.

What fundamentally reversed the normative approach to dependent employment into an area of strongly protected statutory rights is the 1970 reform by Legge n. 300 (Statuto dei Lavoratori) that expressely introduced the so called "real protection" for unlawfully dismissed empoyees in big enterprises. "Real protection" is in opposition to the so called "mandatory protection", and gives the worker the right to claim for being set back in the job position as the dismissal was not happened at all, meaning it is going to be mandatory for the tribunal to compensate him/her as he/her was never actually dismissed, as no real interruption of the employment relation was happened, not just mandatory "to compensate" the worker. Such a new ruling makes the employment process a sort of arena, wherin civil and social concerns are set against the ones to the others, putting judges in a position that easily goes beyond concrete facts, matching political matters, and leading to, possibily, important economic recognition to workers who are in position to rely on procedural terms to gain growing compensations: according to art. 18 of 1970 Legge $n$. 30 the worker being unlawfully fired must be hosted back in his/her place of work ${ }^{2}$ and till then (till the process last), he/she has the right to get back salaries as he/she was never actually fired. The statutory norm did not recognizes external circumstances in respect to the employment relation, and it took a continuous effort by the jurisprudence to make the compensation just flexible on the base of relevant external facts, like

${ }^{2}$ Alternatively to this, he/she can get an indemnity measured on 15 monthly salary. 
for example the employees having entered a new employment contract meanwhile, or his/her peculiar family conditions.

The Italian legislation regarding termination of (dependent) employment has sensibly been reformed in the recent years, also according to the increased recognition due by law to self employment (see Legge n. 81/2017 on independent contractors).

Remaining in the area of dependent work, we see that Italian reforms on unlawfull dismissal as set on place since 2012 to 2018 have produced a severe decrease of the relative judicial claims before the employment tribunals (by 56\%). This means that the new law severely influenced the socio economic context, by reducing the level of unpredictability of employment claims, effectively leading dependent workers to think twice before presenting a claim for injust dismissal.

What essentially changed is that the legal frame now presents the so called "liability rule" in opposition to the "property rule" as the one to be claimed by workes willing to challenge a dismissal: liability is investigated on the part of the employer at facing the employee, and it must be alleged as a matter of fact; contrarily, according to past view, it was the property rule to be applied in favor of employees being fired, and the breach of law was investigated as a sort of detriment to a property right. In other words the matter to be dealt with is the legittimacy of any employer's conduct rather than his duty to grant the work place stability. Such a change of perspective can be read in the increased attention given by the legislator to the many different reasons to dismiss, and particularly to discriminatory reasons, put in relation to different remedies: while discriminatory claims still find strong protection and might lead to important recognition of damages (in addiction to the standard indemnity as a compensation against unfair dismissal), claims against economic dismissal now find a lighter protection that is limited to the standard indemnity, as if the employer is in position to foresee the price of dismissal.

The perspective of work liability, in place of that of the work property, brings along a character of inalienability of the workers' rights, whereas the perspective of the work property implies an objectivization that allows the parties to make economies out from employment relations, easy to be sold and bought.

The legislator also renew the concrete remedy to be assigned too: compensation for unjust dismissal is almost doubled, from a maximum indemnity of 14.000,00 euros the tribunals can now assign an indemnity up to $36.000,00$ euros, which is quite above the European medium level, with the relevant exception of the small enterprise employees, whose indemnity has been decreased.

A different matter from recognition of the compensating indemnity - the statutory fixed remedy that balances private and public interests in measuring compensation - is that of the specific damages that an employee can demonstrate - ex post - to have encountered in the circumstance of the wrongfull dismissal; here the legislator interveened in accordance to many pronounces by the Constitutional Court, by saying that damage derived from illecit actions, as for itself, does not have a Constitutional coverage in its amount, rather it is to be assigned according to a balance with other Constitutional values that might stand in the middle. As it will be said in the next section, damage essentially matters in dismissals for subjective or discriminatory reasons, while it has a limited consideration within the recogniton of the statutory indemnity level in cases of objective dismissals. 


\section{DISMISSAL FOR OBJECTIVE/ECONOMIC REASONS}

Both in common law and civil law a dismissal can be based on subjective reasons, regarding the person of the employee (typically disciplinary reason and breach of contract), or it can based on objective/economic reasons (typically because of an economic crises).

An objective reason to dismiss regards the economic condition of the enterprise, for example an industrial factory needing to convert itself into a new production, or a firm having reduced severely his volume of production; also it could regard an objective condition of the employee, impacting production, for example the manual worker who loses an arm or the intellectual worker who falls into a mental desease. While the dismissal for subjective reason must be investigated and ruled by focusing on the bilateral relationship between the employee and the employer, the dismissal for economic reasons must be inquired and ruled by considering the larger context of the enterprise playing in the market, the enterprise strenght and weakness at facing other economic operators as well as the State as a possibile economic and political player. While the dismissal for subjective reasons implies an investigation over the psychological condition of both parties, and particularly over that of the worker who is first accused to have breached his obligations and duties, the dismissal for objective reasons must be found outside the psychological dymention, amongst those objective circumstances that make possibile for the enterprise to operate and therefor to maintain labour force.

It turns out that discipline over dismissal for economic reasons is typically subjected to the influence of political concerns; for example a fiscal policy that would strongly advantage national capitals might impact the employment policy of foreign enterprises, considering more convenient to move back abroad at detriment of the national employment level. Also, a statutory law that would discipline the dismissal for economic reason in a way to make possibile for the enterprise to forcast the cost of any possible future dismissal, should make it easyer to invest in labour force (and this policy is adopted by the Italian legislator since 2012). Even when political concerns are apparently far from the economic conditions determining the firm's businness and employment, they get at the very centre of the dispute any time the dispute reaches the judicial level: since the judges are called to analyze the connection existing between the economic/technical factor and the employment issue, they are supposed to focus over the reality of facts and to assume an impartial point of observation at the same time in order to decise. For example, a big enterprise could argue that it has the right to resign from a contractual obligation, just submitted with a third party, and implying a certain level of employment rather than a lower; in such a case judges will be called to inquire over the facts grounding the firm right to resign, over the connection existing between those facts and the employment level, reaching a decision that can be more or less pro labour whenever there is no proved direct link between the contractual obligation and employment.

As above recalled, the power of the employer is protected by the Constitution that recognizes the freedom to act economically, insofar this is not contrary to social utility, or performed in such a way to provoke damages on safeness, human liberty and dignity; nevertheless, such a power might be oriented and coordinated by law toward social scopes (art. 41 co. 3), that is what tipically happens when the legislator intervenes with fiscal deductions or mandatory social security deductions.

In Italy the right to dismiss for economic reasons has been ruled for the first time in 1966 by Legge n. 604, and since then, to lawfully dismiss a single worker, or a group of workers, means to allege that organizational, productive, or functional concerns do impede to proceed without decrementing the number of employees (art. 3). 
The dismissal must be notified by the employer to the employee together with written specification of the reasons that led to such a measure; the burden of proof of the dismissal legitimacy is put on the employer (article 5).

Doctrine and jurisprudence set the point ${ }^{3}$ that what must be investigated by judges is the truth over factors determining the organizational, productive or funcional "deficiency" in the factory, not over the employment arrangements adopted a consequence as well, since these arrangements are covered by the Constitutional freedom to exercise economic initiatives: ${ }^{4}$ for example, it must be investigated whether is truth that the employer bought a machine substituting the work previously done by people, whether is truth that the machine is effectively being used to substitute those people, but there cannot be judicial investigation over the choice to buy the machine which decremented employment. Both matters regarding organization, production or functioning of the enterprise and matters regarding the level of employment cannot be judged, since they are covered by Constitution article 41 on freedom to act economically, while the protection of employment as granted by Constitution article 4 requires a statutory intervention in order to let labour rights to prevail and to be balanced ${ }^{5}$. Still there can be seen a normative picture wherein the interest of the State grants and legitimate the interest of enterprises, and therein the enterprises give rise to the workers' rights, so that a prevailing social interest placing labour rights over the enterprise rights could only be highlighted as a sort of an outstanding perspective ${ }^{6}$.

Italian jurisprudence precised that it must be ascertained a nexus between such concerns (the organizational, productive or funcional "deficiency") and the dismissal of that or those specific employees: it is not only necessary that an organizational reason exist for the enterprise to proceed, it is necessary that such an objective reason is directly linked with the one or the plurality of dismissal7. For example, it must be proved that the economic crises attacked the production of shoes rather than that of cloths to lawfully dismiss those employed in the production of shoes.

The jurisprudence had the chance to precise that whenever the enterprise looses its main client, this does not necessarily imply a productive reason (nor organizational, nor functional) to lawfully dismiss, since anything implies a reduction in its productivity already; the firm's capability to find new clients is not touched by the lost of the main client ${ }^{8}$. Neither it can be

3 O. Mazzotta, I licenziamenti economici, un percorso pisano tra diritto e valori, Lectio Magistralis, 2019 November the 13rd, Pisa, recalled that one as the view adopted by Giuseppe Pera right after the 1966 legge n. 604 was released.

4 The same rule has been fixed in a statutory law too, that is article 30 of 2010 Legge n. 183, the s.c. Collegato Lavoro, wanted by Berlusconi's Governament.

${ }^{5}$ Corte di Cassazione, Sez. Lav. Sentenza n. 25201/2016 stated that the general clause set by art. 3 Legge n. $604 / 1966$ does not requires an economic crises for the employer to be free in newely organizing his enterprise; that of balancing article 4 (right to labour) and article 41 (freedom to do business) is not an issue to be judged, but is an issue to eventually be ruled by (statutory) law. What determines the legittimacy of dismissal is the presence of a real purpose to newely organize the firm, the finding of an effective productive or functional change in the asset of the firm.

${ }^{6}$ O. Mazzotta, cited, recalls civil jurist Ugo Natoli's vision, as well as the position adopted by professor Carlo Smuraglia who argues that article 41, in its limiting and shaping the employer's power, can be invoked by workers too.

${ }^{7}$ Corte di Cassazione, Sez. Lav. Sentenza n. 25201/2016.

8 There are dissenting decisions in respect to this: Cassazione, Sentenza 2013 n. 1697 stated that is lawfull to dismiss the secretary of a law firm because of the lost of an important client. 
found legitimacy in the acting of an employer having dismissed someone on the unique purpose to save costs (cutting on workers' salary and compensation).

Moreover, jurisprudence requires employers to search for other available job positions for their employees no longer needed in a certain plant before dismissing them (s.c. duty to "repechage"); to the purpose of lawfully dismissing, the employer can provide a job position requiring also lower skills and lower competences than those owned by the employees. This is now in accordance with 2015 new Civil Code (article 2103, regarding the employee's change of job position), that now makes lawfull any imposed change independently from an evaluation of equivalence between the new job and the job previously done (the latter can be inferior to the former), but for the fact that the new position must be implying the worker to performe a work within the same legal category ${ }^{9}$. This means that before dismissing, the employer is supposed to verify whether is possibile to make the worker do another type of job, also of a lower quality and giving a lower level of remuneration, but being affering to the same legal category as that he was affering to before.

New 2015 legislation over dismissals for objective reasons, applying to workers being employed from 2015 March the 7th on forward, is trying to distinguish the case of discriminatory dismissal, which burden of proof is quite severe to be established, and which consequences are the heaviest to pay for employers (taking back the worker in his job position as no interruption of the employment would have happen, plus paying to the employee a compensatory indemnity corresponding to - minimum 5 - of his monthly salary, which is what can still be called "real protection") from dismissal because of objective reason. These latter are ruled negatively: the legislator refers to them as those not corresponding to discriminatory cases and alike.

The legislator describes as null those dismissals that are based on discriminatory reasons (1), on reason of marriage (2), or on demands for parental leaves (3), or else dismissal to be considered null (legally not effective) because of other statutory provisions (4), or caused by a determinant illecit purpose (5), or not communicated in written form (6); less heavy consequences are disposed for dismissals described as having no juridic effects, that are those which are based on an employee fisical or mental disability (7), or upon a violation of terms recognizing the workers'sickness (8), or upon a fact assuming the employee's subjective responsability that is found to be not really happened (9), or upon a fact that is considered by collective bargaining as one bringing to a permanent disciplinary sanction (10).

Only cases that do not fit in one of those just mentioned above ${ }^{10}$ might follow within the discipline of dismissal lacking of an objective reason to dismiss, which consequence is for the employer to pay a compensatory indemnity ranging from 12 to 36 of the monthly salary, basically counted over the employee's lenght of employment.

About this kind of remedy to provide for any objective dismissal a debate has rised, trying to focus over its real capability to cope with the substantial injustice suffered by employees;

\footnotetext{
${ }^{9}$ According to statutory law (Civil Code article 2095) and collective bargaining, dependent workers can be qualified into four different categories: managers (a category that is mainly ruled by collective contracts), blu collars ("operai"), white collars ("impiegati") and "quadri" (a category standing in the middle between managerial work and white collars' work, introduced in 1985 to refer to those who, although having not a managerial power, do contribute relevantly and continuously to the pursuing of the firm's objectives).

10 Also distinguished - and having even less heavy consequences - are the cases of wrong dismissal grounded on procedural faults and lack of motivation.
} 
international standards for protecting labour, particularly article 24 of the European Charter and 1982 OIL Convention n. 158, have been invoked to affirm that the wrongfull interruption of an employment relationship, although be it happened for an objective reason to dismiss, cannot be ruled like the interruption of "an insurance contract" giving automatically back to the contractor (in this case the employee) a certain numbers of premiums (salaries) he missed to rely upon.

The Constitutional Court in $2018^{11}$ intervened in the debate and concluded by eliminating the part of the 2015 legislation that did not recognize the need to include, into the compensatory indemnity, together with the lost of salary - just linked automatically to the lenght of employment - also the damage just reported by the employee, possibly rising from the consideration of relevant circumstances like the parties's conduct, the level of the enterprise employment, the enterprise economic dimention, the difficulty in finding a new occupation, the family condition. This is obviouly bringing back an increased discretional power on tribunal and judges, deciding upon the lawyers' reasoning.

It is to be noted that the Court argued such conclusion by giving meaning to the Italian Consitutional Charter (both article 4 and 35) as well as to those Constitutional dispositions imposing to the Republic to respect international treaties - and particularly the European Charter on social rights - without referring to a direct binding effect of the European Charter over the ruled private relationships ${ }^{12}$.

11 Corte Costituzionale, Sentenza n. 194/2018.

12 As for the called 1982 OIL Convention, the Court precised that Italy did not ratified it. 